\title{
ВПЛИВ ВУГЛЕЦЕВИХ НАНОЧАСТИНОК НА ГЕПАТОТОКСИЧНІСТЬ ТЕТРАХЛОРМЕТАНУ
}

Вступ. Вуглецеві нанотрубки мають унікальні механічні, електро- та теплопровідні властивості, їх широко застосовують у наукових дослідженнях, промисловості й медицині. Вони є перспективним наноматеріалом для використання в медицині завдяки високому рівню їх біосумісності з кров'ю, кістками, хрящами ім'якими тканинами. Здатність вуглецевих нанотрубок здійснювати транспортування лікарських засобів та хімічних речовин усередину клітини робить актуальним питання про потенційну можливість посилення токсичної дії класичних токсикантів при їх сумісному надходженні в організм з нанотрубками.

Мета дослідження - вивчити здатність вуглецевих нанотрубок впливати на гепатотоксичність тетрахлорметану.

Методи дослідження. Досліди виконано на безпородних щурах-самцях, яким внутрішньочеревно вводили 0,5 мл суспензії одностінкових, багатостінкових чи багатостінкових фрункціоналізованих СОOH нанотрубок (60 мг/кг) окремо або разом із тетрахлорметаном (2 мл/кг). Тварин виводили з експерименту через 3, 6 та 48 год після введення нанотрубок і тетрахлорметану. В сироватці крові визначали активність аланін- і аспартатамінотрансорераз, лужної фоссратази, вміст загального білка та сечовини.

Результати й обговорення. Встановлено, що лише під впливом багатостінкових вуглецевих нанотрубок досліджувані показники зазнавали достовірних змін. Введення щурам тетрахлорметану призводило до виражених змін усіх показників. Максимальні зміни показників зареєстровано у групі тварин, яким сумісно вводили вуглецеві нанотрубки і тетрахлорметан. У цьому випадку активність амінотрансфрераз і лужної фоосфатази достовірно змінювалася порівняно з аналогічними показниками у групі щурів, яким вводили тільки хімічний токсикант.

Висновок. Вуглецеві нанотрубки здатні посилювати гепатотоксичний ефект тетрахлорметану.

КЛЮчОВІ СЛОВА: вуглецеві нанотрубки; тетрахлорметан; гепатотоксичність.

ВСТУП. Нанотехнології активно впроваджують у сучасне життя. В останні роки вони завойовують передові позиції в хімії, біології та медицині $[1,2]$. Важливу роль у розвитку нанотехнологій, 3 огляду на низку виняткових властивостей, відіграють вуглецеві наноматеріали. Вуглецеві нанотрубки (ВНТ) є перспективним наноматеріалом для використання в медицині завдяки високому рівню їх біосумісності з кров'ю, кістками, хрящами і м'якими тканинами $[3,4]$. Здатність нанотрубок проникати крізь клітинні мембрани уможливлює застосування їх для транспортування протеїнів, антигенів і генів, для лікування онкологічних та інших захворювань, а також для доставки різних біомолекул, зокрема ДНК, у живі клітини. Вони можуть проникати через клітинні бар'єри, а також через гематоенцефралічний бар'єр у центральну нервову систему, циркулювати й накопичуватися в органах i тканинах [5, 6]. Нанотрубки здатні накопичува(c) Н. Я. Летняк, М. М. Корда, 2018. тись в ендосомах, мітохондріях, цитоплазмі, ядрі та ядерці й викликати зміни енергетичного метаболізму, рівня вільних радикалів та ушкодження ДНК, стимулюючи виражені патоморфологічні зміни у внутрішніх органах [7-9]. ВНТ є також перспективним матеріалом для використання в галузі тканинної інженерії для регенерації тканин. Вуглецеві наночастинки характеризуються малими розмірами та великою сумарною площею поверхні, що в поєднанні з іншими фрізико-хімічними властивостями, такими, як наявність домішок та заряду на поверхні, може проявляти досить непрогнозовані токсичні властивості [10-12]. Крім прямого впливу вуглецевих нанотрубок на клітини, існує можливість їх взаємодії 3 класичними токсикантами, наприклад тетрахлорметаном (ТХМ). Питання про біологічні есректи наночастинок при їх надходженні в організм разом із традиційними токсикантами залишаються недослідженими. Зважаючи на це, особливої уваги потребують дослідження з усе- 
бічного вивчення токсикологічних властивостей вуглецевих нанотрубок безпосередньо та при спільному введенні їх в організм із токсикантом.

Мета дослідження - вивчити здатність вуглецевих нанотрубок впливати на гепатотоксичність тетрахлорметану.

МЕТОДИ ДОСЛІДЖЕННЯ. Досліди виконано на безпородних щурах-самцях масою 160 г, яких утримували на стандартному раціоні віварію. Одностінкові (ОВНТ), багатостінкові (БВНТ) та багатостінкові функціоналізовані (БВНТ-СООН) нанотрубки вводили тваринам у вигляді суспензії (0,5 мл) інтраперитонеально в дозі 60 мг/кг. Тетрахлорметан вводили інтраперитонеально одноразово у вигляді 50 \% олійного розчину в дозі 2 мл/кг. Для виконання експерименту щурів було поділено на 8 груп: 1-ша - контрольна (інтактні тварини, яким вводили фрізрозчин у дозі 0,5 мл/кг); 2-га - щури, яким вводили ОВНТ; 3-тя - тварини, яким вводили БВНТ; 4-та - щури, яким вводили БВНТ-СООН; 5-та - тварини, яким вводили ТХМ; 6-та - щури, яким вводили суспензію ОВНТ разом із ТХМ; 7-ма - тварини, яким вводили суспензію БВНТ+ТХМ; 8-ма - щури, яким вводили суспензію БВНТ-COOH+ТХМ. Тварин виводили з експерименту під тіопенталовим наркозом через 3, 6 і 48 год після ін'єкції. Об'єктом дослідження слугувала сироватка крові щурів.

Утримували щурів та проводили експерименти на них відповідно до положень Європейської конвенції про захист хребетних тварин, що використовуються для дослідних та інших наукових цілей.

У сироватці крові визначали активність аланінамінотрансорерази (АлАТ), аспартатамінотрансорерази (АсАТ), лужної фроссратази (ЛФ), вміст загального білка та сечовини за загальноприйнятими методами на напівавтоматичному аналізаторі HUMALYZER 2000 з використанням стандартних наборів реагентів фрірми "Human" (Німеччина). В експерименті застосовували нанопорошок одностінкових карбонових нанотрубок (SWCN, $90 \%, 1-2$ nm), багатостінкових нанотрубок (MWCN, 99 \%, 13-18 nm) та карбоксифрункціоналізовані нанотрубки (MWCN-COOH, $95 \%, 30-50 \mathrm{~nm}$ ) виробництва "USResearch Nanomaterials, Inc." (США). Як модельний токсикант використовували тетрахлорметан виробництва "Макрохім" (Україна).

Статистичну обробку результатів виконано у відділі системних статистичних досліджень Тернопільського державного медичного університету імені І. Я. Горбачевського в програмному пакеті Statsoft STATISTICA. Порівнювали отримані величини з використанням непараметричного критерію Манна-Уїтні. Зміни вважали статистично достовірними при $р<0,05$.

РЕЗУЛЬТАТИ Й ОБГОВОРЕННЯ. ЯК пОкаЗали результати наших досліджень (табл. 1), введення тваринам суспензії вуглецевих нанотрубок викликало зміни активності в сироватці крові фрерментів маркерів цитолізу - АлАТ і АсАТ, а також активності ЛФ. Зокрема, достовірно збільшувалася активність АлАТ на 3-тю і 6-ту год 3 моменту введення розчину БВНТ (в 1,3 та 1,4 раза), а також на 6-ту год експерименту в щурів, яким вводили ОВНТ і БВНТ-СООН (в 1,2 та 1,3 раза). Аналогічно підвищувалася активність АсАТ. Отже, результати досліджень активності цитозольних ферментів АлАТ та АсАТ у плазмі крові вказують на порушення структури і фрункцій клітинних мембран у тварин, яким вводили ВНТ. Достовірне зростання активності ЛФ зафріксовано на 6-ту год експерименту лише в щурів, яким вводили БВНТ.

Здатність гепатоцитів до синтезу білка й азотовмісних продуктів під впливом ВНТ суттєво

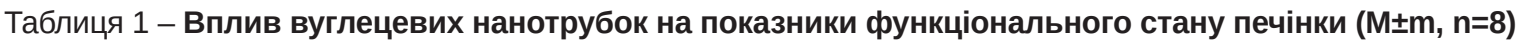

\begin{tabular}{|c|c|c|c|c|c|c|c|c|c|c|}
\hline \multirow{4}{*}{ Показник } & \multicolumn{10}{|c|}{ Група тварин } \\
\hline & \multirow{3}{*}{ інтактні } & \multicolumn{3}{|c|}{ OBHT } & \multicolumn{3}{|c|}{ БВНТ } & \multicolumn{3}{|c|}{ БBHT-COOH } \\
\hline & & \multicolumn{9}{|c|}{ час після введення, год } \\
\hline & & 3 & 6 & 48 & 3 & 6 & 48 & 3 & 6 & 48 \\
\hline \multicolumn{11}{|c|}{ Плазма крові } \\
\hline $\begin{array}{l}\text { АлАТ, } \\
\text { Од/л }\end{array}$ & $\begin{array}{c}58,09 \pm \\
2,28\end{array}$ & $\begin{array}{c}65,84 \pm \\
3,75\end{array}$ & $\begin{array}{c}71,09 \pm \\
5,08^{*}\end{array}$ & $\begin{array}{c}59,74 \pm \\
4,18\end{array}$ & $\begin{array}{c}74,63 \pm \\
4,38^{*}\end{array}$ & $\begin{array}{c}80,25 \pm \\
4,75^{\star}\end{array}$ & $\begin{array}{c}62,48 \pm \\
3,19\end{array}$ & $\begin{array}{c}69,33 \pm \\
4,76\end{array}$ & $\begin{array}{c}73,87 \pm \\
4,89^{*}\end{array}$ & $\begin{array}{c}63,12 \pm \\
4,07\end{array}$ \\
\hline $\begin{array}{l}\text { AсAT, } \\
\text { Од/л }\end{array}$ & $\begin{array}{c}142,24 \pm \\
12,11\end{array}$ & $\begin{array}{c}166,81 \pm \\
13,07\end{array}$ & $\begin{array}{c}186,33 \pm \\
15,79^{*}\end{array}$ & $\begin{array}{c}150,92 \pm \\
13,81\end{array}$ & $\begin{array}{c}189,74 \pm \\
15,99^{*}\end{array}$ & $\begin{array}{c}192,08 \pm \\
16,28^{*}\end{array}$ & $\begin{array}{c}159,06 \pm \\
12,93\end{array}$ & $\begin{array}{c}182,85 \pm \\
15,18\end{array}$ & $\begin{array}{c}191,23 \pm \\
16,02^{*}\end{array}$ & $\begin{array}{c}148,13 \pm \\
14,03\end{array}$ \\
\hline ЛФ, Од/л & $\begin{array}{c}249,71 \pm \\
15,22\end{array}$ & $\begin{array}{c}273,79 \pm \\
19,81\end{array}$ & $\begin{array}{c}294,95 \pm \\
21,01\end{array}$ & $\begin{array}{c}251,03 \pm \\
19,03\end{array}$ & $\begin{array}{c}297,30 \pm \\
21,73\end{array}$ & $\begin{array}{c}319,81 \pm \\
23,91^{*}\end{array}$ & $\begin{array}{c}273,52 \pm \\
19,11\end{array}$ & $\begin{array}{c}288,93 \pm \\
20,04\end{array}$ & $\begin{array}{c}303,21 \pm \\
22,19\end{array}$ & $\begin{array}{c}268,85 \pm \\
19,74\end{array}$ \\
\hline $\begin{array}{l}\text { Загальний } \\
\text { білок, г/л }\end{array}$ & $\begin{array}{c}69,03 \pm \\
2,81\end{array}$ & $\begin{array}{c}66,19 \pm \\
2,34\end{array}$ & $\begin{array}{c}63,96 \pm \\
3,08\end{array}$ & $\begin{array}{c}68,56 \pm \\
2,48 \\
\end{array}$ & $\begin{array}{c}64,01 \pm \\
3,38\end{array}$ & $\begin{array}{c}60,96 \pm \\
2,43\end{array}$ & $\begin{array}{c}67,25 \pm \\
2,99\end{array}$ & $\begin{array}{c}65,18 \pm \\
3,22 \\
\end{array}$ & $\begin{array}{c}62,17 \pm \\
3,75\end{array}$ & $\begin{array}{c}68,74 \pm \\
2,97 \\
\end{array}$ \\
\hline $\begin{array}{l}\text { Сечовина, } \\
\text { ммоль/л }\end{array}$ & $\begin{array}{c}6,18 \pm \\
0,90\end{array}$ & $\begin{array}{c}6,09 \pm \\
0,71\end{array}$ & $\begin{array}{c}5,87 \pm \\
0,49\end{array}$ & $\begin{array}{c}6,22 \pm \\
0,58\end{array}$ & $\begin{array}{c}5,53 \pm \\
0,53\end{array}$ & $\begin{array}{c}4,93 \pm \\
0,42\end{array}$ & $\begin{array}{c}5,81 \pm \\
0,50\end{array}$ & $\begin{array}{c}5,87 \pm \\
0,45\end{array}$ & $\begin{array}{c}5,14 \pm \\
0,43\end{array}$ & $\begin{array}{c}6,02 \pm \\
0,48\end{array}$ \\
\hline
\end{tabular}

Примітка. Тут і в таблиці 2: * - зміни достовірні порівняно з контролем (p<0,05). 
не змінилася. Зокрема, вміст загального білка та сечовини в сироватці крові тварин, яким вводили ВНТ, дещо зменшувався, проте без достовірних змін.

До вираженого цитолізу гепатоцитів призвело введення тваринам ТХМ. Як свідчать дані, наведені в таблиці 2, зростання активності амінотрансфрераз у плазмі крові відмічено в усі терміни дослідження ( $<<0,05)$, однак максимальне збільшення даних показників зафіксовано на 6-ту год експерименту (в 2,8 раза - АлАТ та у 2,4 раза - АсАТ відносно інтактних тварин). Підвищення активності в плазмі крові цих ензимів вказує на порушення цілісності гепатоцитів і є надійним індикатором гострих уражень печінки.

На ураження печінки ТХМ також вказували виражене підвищення активності ЛФ і зниження вмісту загального білка та сечовини в крові.

Максимальні зміни біохімічних показників фрункціонального стану печінки зафріксовано у тварин, яким одночасно вводили тетрахлорметан і вуглецеві нанотрубки (табл. 3). У щурів цієї групи спостерігали достовірні зміни всіх досліджуваних показників відносно інтактних тварин в усі терміни дослідження. Слід зазначити, що у тварин даної групи активність маркерних фрерментів цитолізу та лужної фросфратази була достовірно вищою порівняно з такими ж показниками у відповідні терміни у тварин, яким вводили тетрахлорметан без нанотрубок. На вміст загального білка та сечовини в сироватці крові сумарне застосування нанотрубок і тетрахлорметану достовірного ефекту, порівняно з впливом тільки хімічного токсиканта, не справило.

3 огляду на такі результати, можна зробити висновок, що здатність хімічного токсиканта тетрахлорметану проявляти гепатотоксичний ефрект достовірно зростає при його сумісному введенні з вуглецевими нанотрубками. Отже, нанотрубки і тетрахлорметан взаємодіють синергічно щодо індукції цитолітичного ушкодження печінки, що проявляється, зокрема, інтенсивнішим виходом у кров амінотрансорераз і лужної фоссратази. Найбільш імовірним поясненням вказаного синергізму токсичності досліджуваних чинників може бути ефрект посилення біодоступності тетрахлорметану, що зумовлено здатністю вуглецевих нанотрубок абсорбувати на своїй поверхні токсин та сприяти його транспорту до тканин і клітин. Адже, як відомо, однією із властивостей нанотрубок є здатність виступати пере-

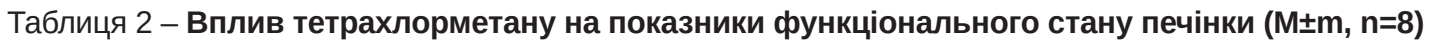

\begin{tabular}{|c|c|c|c|c|}
\hline \multirow{4}{*}{ Показник } & \multicolumn{4}{|c|}{ Група тварин } \\
\hline & \multirow{3}{*}{ інтактні } & \multicolumn{3}{|c|}{ TXM } \\
\hline & & \multicolumn{3}{|c|}{ час після введення, год } \\
\hline & & 3 & 6 & 48 \\
\hline \multicolumn{5}{|c|}{ Плазма крові } \\
\hline АлАТ, Од/л & $58,09 \pm 2,28$ & $151,98 \pm 6,05^{*}$ & $163,60 \pm 7,32^{*}$ & $128,23 \pm 6,78^{*}$ \\
\hline АсАТ, Од/л & $142,24 \pm 12,11$ & $332,92 \pm 19,08^{*}$ & $351,37 \pm 20,85^{\star}$ & $268,82 \pm 18,54^{*}$ \\
\hline ЛФ, Од/л & $249,71 \pm 15,22$ & $464,67 \pm 19,36^{*}$ & $519,53 \pm 23,08^{*}$ & $312,51 \pm 21,85^{\star}$ \\
\hline Загальний білок, г/л & $69,03 \pm 2,81$ & $60,10 \pm 2,35^{\star}$ & $58,61 \pm 3,07^{*}$ & $56,34 \pm 2,75^{\star}$ \\
\hline Сечовина, ммоль/л & $6,18 \pm 0,90$ & $5,08 \pm 0,48^{\star}$ & $4,57 \pm 0,32^{\star}$ & $5,83 \pm 0,35^{\star}$ \\
\hline
\end{tabular}

Таблиця 3 - Вплив поєднаного застосування вуглецевих нанотрубок

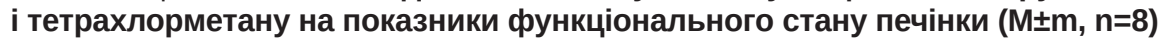

\begin{tabular}{|c|c|c|c|c|c|c|c|c|c|c|}
\hline \multirow{4}{*}{ Показник } & \multicolumn{10}{|c|}{ Група тварин } \\
\hline & \multirow{3}{*}{ інтактні } & \multicolumn{3}{|c|}{ OBHT+TXM } & \multicolumn{3}{|c|}{ БBHT+ТХM } & \multicolumn{3}{|c|}{ БВНТ-COOH+ТХM } \\
\hline & & \multicolumn{9}{|c|}{ час після введення, год } \\
\hline & & 3 & 6 & 48 & 3 & 6 & 48 & 3 & 6 & 48 \\
\hline \multicolumn{11}{|c|}{ Плазма крові } \\
\hline АлАТ, & $58,09 \pm$ & $131,13 \pm$ & $178,47 \pm$ & $125,34 \pm$ & $145,19 \pm$ & $198,21 \pm$ & $133,19 \pm$ & $143,75 \pm$ & $189,67 \pm$ & $129,92 \pm$ \\
\hline Од/л & 2,28 & $7,05^{\star}$ & $7,93^{*}$ & $6,22^{*}$ & $5,97^{\star \#}$ & $6,33^{\star \#}$ & $5,77^{\star}$ & $6,85^{\star \#}$ & $7,13^{\star \#}$ & $6,45^{\star}$ \\
\hline ЛФ, & $249,71 \pm$ & $472,85 \pm$ & $545,51 \pm$ & $365,12 \pm$ & $525,62 \pm$ & $605,22 \pm$ & $381,77 \pm$ & $489,97 \pm$ & $563,36 \pm$ & $373,72 \pm$ \\
\hline Од/л & 15,22 & $25,08 *$ & $28,13^{\star}$ & 27,66 & $25,44^{\star}$ & $26,81^{\text {*\# }}$ & $25,23^{*}$ & $27,01^{*}$ & $27,91^{\star}$ & $25,72^{\star}$ \\
\hline Загальний & $69,03 \pm$ & $58,87 \pm$ & $51,99 \pm$ & $52,18 \pm$ & $55,79 \pm$ & $49,92 \pm$ & $51,10 \pm$ & $57,28 \pm$ & $50,63 \pm$ & $52,88 \pm$ \\
\hline білок, г/л & 2,81 & $2,21^{\star}$ & 1,98* & $2,05^{*}$ & $2,45^{\star}$ & 1,83* & $2,09 *$ & $2,20 *$ & $1,91^{*}$ & $2,10^{\star}$ \\
\hline
\end{tabular}

Примітки:

1. * - зміни достовірні порівняно з контролем $(p<0,05)$.

2. \# - зміни достовірні порівняно з групою тварин, яким вводили тетрахлорметан $(p<0,05)$. 
носником фрізіологічно активних речовин, ксенобіотиків та лікарських засобів.

3 огляду на результати наших досліджень, слід зазначити, що серед усіх нанотрубок максимальну токсичність проявили багатостінкові нанотрубки (MWCN, 99 \%, 13-18 nm, MWCN$\mathrm{COOH}, 95$ \%, 30-50 nm). Відомо, що 3 фрізикохімічних властивостей у реалізації токсичної дії наночастинок мають значення 2 показники розмір (діаметр) частинки та загальна поверхня. Так, дрібні наночастинки веретеноподібної фрорми викликають більш руйнівні ефекти в організмі, ніж подібні до них частки сореричної фрорми. Встановлено, що частинки розміром 5-100 нм мають найбільшу біодоступність, а отже, найвищий токсичний ризик [13-15].

ВИСНОВОК. Вуглецеві нанотрубки здатні посилювати гепатотоксичний ефект тетрахлорметану. Механізм такого синергічного едректу хімічного токсину і наночастинок потребує подальшого дослідження.

Перспективи подальших досліджень. Для безпечного використання нанотехнологій необхідні подальші біохімічні дослідження, спрямовані на вивчення механізмів синергічного впливу вуглецевих наночастинок і ксенобіотиків хімічної природи на організм.

\section{СПИСОК ЛІТЕРАТУРИ}

1. Наночастицы и нанотехнологии в медицине сегодня и завтра / Л. Ф. Абаева, В.И.Шумский, Е. Н. Петрицкая [и др.] // Альм. клинич. медицины. 2010. - № 22. - C. 10-16.

2. Чекман И. С. Нанотехнологии, наномедицина, нанофрармакология, нанофрармация: внедрение результатов в медицинскую практику / И. С. Чекман // Пробл. ендокринної патології. - 2014. - № 1. -С. 80-94.

3. Микитюк М.В.Наночастинки та перспективи їх застосування в біології і медицині / М. В. Микитюк // Пробл. екології та медицини. - 2011. - № 5-6. C. 41-49.

4. Ротко Д. М. Вуглецеві нанотрубки як новітні матеріали для нейроінженерії / С. В. Прилуцька, К. І. Богуцька // Біотехнологія. - 2011. - 4, № 5. C. 9-24.

5. Наукові основи наномедицини, нанофармакології та наносрармації / В. Ф. Москаленко, В.М.Лісовий, І. С. Чекман [та ін.] // Наук. вісн. Нац. мед. ун-ту ім. О. О. Богомольця. - 2009. - № 2. - С. 17-31.

6. Прилуцька С. В. Токсичність вуглецевих наноструктур у системах in vitro та in vivo / С. В. Прилуцька, Д. М. Ротко, Ю.І.Прилуцький // Сучасні пробл. токсикології. - 2012. - 3/4. - С. 49-57.

7. Возможности биомедицинского применения углеродных нанотрубок / И. В. Митрофанова, В. И. Мильто, И. В. Суходоло, Г. Ю. Васюков // Бюлл. сибир. медицины. - 2014. - 13, № 1. - С. 135-144.

8. Вуглецеві нанотрубки як новий клас матеріалів для нанобіотехнології / С. В. Прилуцька, О.В.Ременяк, Ю. В. Гончаренко [та ін.] // Біотехнологія. - 2009. - 2, № 2. - C. 55-66.

\section{REFERENCES}

1. Abayeva, L.F., Shumskiy, V.I., Petritskaya, E.N., Rogatkin, D.A., \& Lyubchenko, P.N. (2010). Nanochastitsy i nanotekhnologii $v$ meditsine segodnya i zavtra [Nanoparticles and nanotechnologies in medicine today
9. Чекман І. С. Наногенотоксикологія: вплив наночастинок на клітину / І. С. Чекман, М. О. Говоруха, А. М. Дорошенко // Укр. мед. часоп. - 2011. - № 1 (81), I/II. - C. 30-35.

10. Нанотехнологии и перспективы их использования в медицине и биотехнологии / В. М. Лахтин, С. С. Афранасьев, М. В. Лахтин [и др.] // Вестн. РАМН. 2008. - № 4. - С. 50-55.

11. Проданчук Н. Г. Нанотоксикология: состояние и перспективы исследований / Н. Г. Проданчук, Г. М. Балан // Сучасні пробл. токсикології. - 2009. № 3/4. - C. 4-20.

12. Evaluation of the genotoxic potential of single-wall carbon nanotubesby using a battery of in vitro and in vivo genotoxicity assays / M. Naya, N. Kobayashi, K. Mizuno [et al.] // Regul. Toxicol. Pharmacol. - 2011. - 61. P. 192-198.

13. Primary study on the hepatotoxicity and nephrotoxicity of rats induced by three kinds of nanomaterials / B. C. Lin, Z. G. Xi, Y. G. Zhang, H. S. Zhang // Wei Sheng Yan Jiu. - 2008. - 37. - P. 651-653.

14. Patlolla A. K. Study of hepatotoxicity and oxidative stress in male Swiss-Webster mice exposed to functionalized multi-walled carbon nanotubes / A. K. PatIolla, A. Berry, P. B. Tchounwou // Mol. Cell Biochem. 2011. - No. 358 (1-2). - P. 189-199.

15. Lin B. C. Studies of single-walled carbon nanotube-induced hepatotoxicity by NMR-based metabonomics of rat blood plasma and liver extracts / B. C. Lin, N. S. Zhang // Nanoscale Research Letters. - 2013. 8. - P. 236

and tomorrow]. Almanakh klinicheskoy meditsiny - Almanac of Clinical Medicine, 22, 10-16 [in Russian].

2. Chekman, I.S. (2014). Nanotekhnologii, nanomeditsyna, nanofarmakologiya, nanofarmatsiya vnedre- 
nye rezultatov $v$ medytsynskuyu praktiku [Nanotechnology, nanomedicine, nanopharmacology, nanopharmacy: implementation of results in medical practice]. Problemy endokrynnoi patolohii - Problems of Endocrine Pathology, 1, 80-94 [in Ukrainian].

3. Mykytyuk, M.V. (2011). Nanochastynky ta perspektyvy yikh zastosuvannia v biolohii i medytsyni [Nanoparticles and prospects for their application in biology and medicine]. Problemy ekolohii ta medytsyny - Problems of Ecology and Medicine, 5-6, 41-49 [in Ukrainian].

4. Rotko, D.M., Prylutska, S.V., Bohutska, K.I. (2011). Vuhletsevi nanotrubky yak novitni materialy dlia neiroinzhenerii [Toxicity of carbon nanostructures in in vitro and in vivo systems]. Biotekhnolohiia naukovyi zhurnal Biotechnology Scientific Journal, 4 (5), 9-24 [in Ukrainian].

5.Moskalenko, V.F., Lisovyi, V.M., Chekman, I.S. (2009). Naukovi osnovy nanomedytsyny, nanofarmakolohii ta nanofarmatsii [Scientific fundamentals of nanomedicine, nanopharmacology and nanopharmaceuticals]. Naukovyy visnyk Natsionalnoho medychnoho universytetu im. O.O. Bohomoltsia - Scientific Journal of O.O. Bohomolets National Medical University, 2, 17-31 [in Ukrainian].

6. Prylutska, S.V., Rotko, D.M., Prylutskyi, lu.I. (2012). Toksychnist vuhletsevykh nanostruktur u systemakh in vitro ta in vivo [Toxicity of carbon nanostructures in in vitro and in vivo systems]. Suchasni problemy toksykolohii-Modern Problems of Toxicology, 3/4, 49-57 [in Ukrainian].

7. Mitrofanova, I.V., Milto, I.V., Suhodolo, I.V., Vasyukov, G.Yu. (2014). Vozmozhnosti biomeditsinskogo primeneniya uglerodnykh nanotrubok [Opportunnities of biomedical use of carbon nanotubes]. Byul. Sib. Med. Bulletin of Siberian Medicine, 13 (1), 135-144 [in Russian].

8. Prylutska, S.V., Remeniak, O.V., Honcharenko, lu.V. (2009). Vuhletsevi nanotrubky yak novyi klas materialiv dlia nanobiotekhnolohii [Carbon nanotubes as a new class of materials for nanobiotechnology]. Biotekhnolohiia Biotechnology, 2 (2), 55-66 [in Ukrainian].

9. Chekman, I.S. (2009). Nanochastynky: vlastyvosti ta perspektyvy zastosuvannia [Nanoparticles: properties and usage perspectives]. Ukrainskyi biokhimichnyi zhurnal - Ukrainian Biochemistry Journal, 1 (81), 122-129 [in Ukrainian].

10. Lakhtyn, V.M., Afanasyev, S.S., \& Lakhtyn, M.V. (2008). Nanotekhnologii i perspektivy ikh ispolzovaniya v meditsyne i biotekhnologii [Nanotechnologies and prospects for their use in medicine and biotechnology]. Vestn. RAMN - Journal of RAMN, 4, 50-55 [in Russian].

11. Prodanchuk, N.H., \& Balan, H.M. (2009). Nanotoksikologiya: sostoyanie i perspektivy issledovaniy [Nanotoxicology: the state and prospects of research]. Suchasni problemy toksykolohii - Modern Problems of Toxicology, (4), 4-19 [in Russian].

12. Naya, M., Kobayashi, N., Mizuno, K., Matsumoto, K., Ema, M., \& Nakanishi, J. (2011). Evaluation of the genotoxic potential of single-wall carbon nanotubesby using a battery of in vitro and in vivo genotoxicity assays. Regul. Toxicol. Pharmacol., 61, 192-198.

13. Lin, B.C., Xi, Z.G., Zhang, Y.G., \& Zhang, H.S. (2008). Primary study on the hepatotoxicity and nephrotoxicity of rats induced by three kinds of nanomaterials. Wei Sheng Yan Jiu, 37, 651-653.

14. Patlolla, A.K., Berry, A., \& Tchounwou, P.B. (2011). Study of hepatotoxicity and oxidative stress in male Swiss-Webster mice exposed to functionalized multiwalled carbon nanotubes. Mol Cell Biochem., 358 (1-2), 189-199.

15. Lin, B.C., \& Zhang, H.S. (2013). Studies of singlewalled carbon nanotube-induced hepatotoxicity by NMRbased metabonomics of rat blood plasma and liver extracts. Nanoscale Research Letters, 8, 236.

\section{ВЛИЯНИЕ УГЛЕРОДНЫХ НАНОЧАСТИЦ НА ГЕПАТОТОКСИЧНОСТЬ ТЕТРАХЛОРМЕТАНА}

\section{Резюме}

Вступление. Углеродные нанотрубки обладают уникальными механическими, электро- и теплопроводными свойствами, их широко применяют в научных исследованиях, промышленности и медицине. Они являются перспективным наноматериалом для использования в медицине благодаря высокому уровню их биосовместимости с кровью, костями, хрящами и мягкими тканями. Способность углеродных нанотрубок осуществлять транспортировку лекарственных средств и химических веществ внутрь клетки делает актуальным вопрос о потенциальной возможности усиления токсического действия классических токсикантов при их совместном поступлении в организм с нанотрубками.

Цель исследования - изучить способность углеродных нанотрубок влиять на гепатотоксичность тетрахлорметана.

Методы исследования. Опыты выполнены на беспородных крысах-самцах, которым внутрибрюшно вводили 0,5 мл суспензии одностеночных, многостеночных или многостеночных фрункционализированных СООН нанотрубок (60 мг/кг) отдельно или вместе с тетрахлорметаном (2 мл/кг). Животных выво- 
дили из эксперимента через 3, 6 и 48 часов после введения нанотрубок и тетрахлорметана. В сыворотке крови определяли активность аланин- и аспартатаминотрансфераз, щелочной фросфратазы, содержание общего белка и мочевины.

Результаты и обсуждение. Установлено, что только под влиянием многостеночных углеродных нанотрубок исследуемые показатели испытывали достоверные изменения. Введение крысам тетрахлорметана приводило к выраженным изменениям всех показателей. Максимальные изменения показателей зарегистрированы в группе животных, которым совместно вводили углеродные нанотрубки и тетрахлорметан. В этом случае активность аминотрансфрераз и щелочной фросфратазы достоверно изменялась по сравнению с аналогичными показателями в группе крыс, которым вводили только химический токсикант.

Вывод. Углеродные нанотрубки способны усиливать гепатотоксический эфрфект тетрахлорметана.

КЛЮЧЕВЫЕ СЛОВА: углеродные нанотрубки; тетрахлорметан; гепатотоксичность.

N. Ya. Letniak, M. M. Korda

I. HORBACHEVSKY TERNOPIL STATE MEDICAL UNIVERSITY

\section{THE EFFECT OF CARBON NANOPARTICLES ON THE TETRACHLOROMETHANE HEPATOTOXICITY}

\section{Summary}

Introduction. Carbon nanoparticles have unique mechanical, electrical and thermal properties and are widely used in scientific research, industry and medicine. They are a promising nanomaterial for medical use due to their really high biocompatibility with blood, bones, cartilages and soft tissues. The capability of nanotubes to transport medicines and chemicals inside a cell predicts the possibility of the increase of classical substances toxicity in case of their intake into the body together with nanotubes.

The aim of the study - to determine how nanoparticles affect the hepatotoxic properties of tetrachloromethane.

Research Methods. The experiments were performed on outbred male rats, which were administered intraperitoneally with $0.5 \mathrm{ml}$ of suspension of single-walled, multi-walled or multi-walled functionalized by COOH nanotubes $(60 \mathrm{mg} / \mathrm{kg}$ ) separately or together with tetrachlormethane $(2 \mathrm{ml} / \mathrm{kg})$. The animals were taken out of the experiment in 3, 6 and 48 hours after the administration of the nanotubes and tetrachlormethane. Alanine and aspartate transaminases, alkaline phosphatase activities, as well as total protein and urea contents were measured in rat blood plasma.

Results and Discussion. It has been shown that only multi-walled carbon nanotubes changed significantly the studied parameters. The administration of tetrachloromethane to rats caused significant changes of all indices. Maximal changes of all parameters were registered in the group of animals that were co-administered with carbon nanotubes and tetrachloromethane. In this case, activities of transaminases and alkaline phosphatase in blood significantly changed compared to the similar indicators in the group of animals, which were administered with the chemical toxicant only.

Conclusion. Carbon nanotubes enhance the negative hepatotoxic effects of tetrachlormethane.

KEY WORDS: carbon nanotubes; tetrachloromethane; hepatotoxicity.

Отримано 04.01.18

Адреса для листування: Н. Я. Летняк, Тернопільський державний медичний університет імені І. Я. Горбачевського, майдан Волі, 1 , Тернопіль, 46001, Україна, e-mail: letnyak@tdmu.edu.ua. 